\title{
Multiculturalism and the Millennium: Global Perspectives
}

\author{
Anthony H. Richmond
}

\begin{abstract}
The author confronts the conundrum of the "multicultural world" under attack. Can multicultural policies withstand the impact of globalization, postmodernism and the "information superhighway?" He concludes that disintegration and fragmentation are possible but not necessary outcomes. Survival is dependent on both public and private sectors working together to achieve "unity in diversity."
\end{abstract}

\section{Précis}

La question centrale posée par cet article est: la politique fédérale en matière de multiculturalisme arrivera-t-elle à assurer sa survie dans un vingt-et-unième siècle soumis à l'impact grandissant de la globalisation, du postmodernisme et de la méga-autoroute de l'information? L'auteur conclut que la désintégration et la fragmentation de la politique multiculturelle sont des aboutissements possibles mais non inévitables. De fait, les secteurs public et privé se doivent d'agir conjointement pour arriver à assurer l'unité dans la diversité.

One of the ironies of the multicultural world in which we live is that, as diversity increases, so does the temptation to impose uniformity. On the one hand majorities, and formerly dominant classes, feel threatened by the rapid social and cultural changes that undermine their hegemony. They would like to exclude people and ideas that threaten their sense of security. On the other hand, newly empowered minorities would like to impose their own agenda, determining the content of

\footnotetext{
Anthony H. Richmond is Professor Emeritus, Sociology, York University, Toronto.

Excerpted from a paper presented at the conference on "Devolution of Settlement Services," Centre for Refugee Studies, February 16-18, 1996.
}

school curricula and rewriting history (or herstory) to fit their ownideologies. New orthodoxies battle old fundamentalisms, in religion and in politics. "Political correctness" becomes a source of intolerance-zero tolerance of prejudice and discrimination becomes an excuse for new forms of inquisition. The empowerment of minorities is no guarantee of freedom of speech, or greater tolerance of diversity. Like the White Queen in Alice in Wonderland, "off with their heads" is often the response of those who seek to redress past wrongs ... 1

\section{Multiculturalism}

We need to examine more closely just what is meant by "multiculturalism." cophone minorities in the rest of Canada.

In due course, "multiculturalism" was translated into bureaucratic offices and institutions. The first step by the federal government, in the early 1970 's, was to create a Multiculturalism Directorate, under the auspices of the Secretary of State and to give it a modest budget. At first, the programs funded were of the cultural heritage type. Histories of ethnic populations in Canada were commissioned, language classes and textbooks subsidized, and folk-singing and dance groups supported. ${ }^{2}$ Most of these grants went in support of the already well established ethnic communities in Canada, of mainly European descent. Some prov-

\section{"Political correctness" becomes a source of intolerance-zero tolerance of prejudice and discrimination becomes an excuse for new forms of inquisition.}

It can be a purely descriptive term indicating the extent of ethnic diversity of contemporary societies. It can also be prescriptive, setting out certain ideals, such as respect for cultural differences, equality of opportunity and freedom of expression. From a policy perspective such goals may be embodied in legislative and administrative programs. The term came into circulation in 1971, following the publication of Volume 4 of the Royal Commission on Bi-lingualism and Bi-culturalism. The latter dealt with the situation of the so-called "Other" ethnic groups, i.e., those not of British or French origin. The term "multiculturalism" was officially endorsed when Prime Minister Trudeau announced a policy of "Multiculturalism within a bilingual framework." It is important to remember that as a policy it was always subordinate to the government's concern with the status of Quebec in Confederation, and with the situation of fran- inces followed suit with similar programs paralleling or supplementing the federal ones.

The second step came when the 1867 British North America Act was repatriated and became the Constitution of Canada in 1982. Attached to the new Constitution was a Charter of Rights and Freedoms, which spelled out the government's commitment more explicitly. Section 27 referred to the "preservation and enhancement of the multicultural heritage of Canadians," and section 15 embodied an "equality rights" clause, which banned all forms of discrimination, and legitimated affirmative action to remedy past wrongs. There followed, in due course, various federal and provincial employment equity programs directed toward women, visible minorities and the disabled. In turn these complemented the work of Human Rights Commissions, and complaints procedures, which had been in place even 
before "multiculturalism" became official.

Later (1988), the federal government passed the Multiculturalism Act and created a separate Department of Multiculturalism with a broader mandate and promise of additional funding. New goals were articulated, among which educational and other measures to combat racism figured prominently. Lobbying by Japanese Canadians led to the promise (yet to be fulfilled) of a "Race Relations Foundation" that would undertake research and education, designed to reduce the incidence of racism in Canada. Other groups, who subsequently sought similar apologies and possible compensation for the discrimination that they, or their ancestors, had experienced were less successful in establishing their claims. Meanwhile, Provincial governments went ahead with multicultural policies and employment equity programs designed to increase access to jobs and promotion for women, the disabled and socalled "visible minorities."

However, it is now obvious that there has been a political backlash against such programs in Canada, as in the United States. They are being seen as divisive and threatening existing power structures. Globalization has brought economic insecurity, heightened competition and high rates of unemployment. These are precisely the conditions likely to lead to greater ethnic conflict and overt racism. Multiculturalism, both as an ideology and as government practise, has come under extensive fire in recent years. There are several types of criticism, which I call the radical, the liberal/humanist, the communitarian, the neo-conservative and the objectivist, respectively.

1) The radical criticism of multiculturalism applauds the means and the goals, butconsiders that actual policies and programs have not gone far enough and have not yet succeeded in achieving their goals. Critics in this school of thought point to the persistence of ethnic discrimination, high rates of unemployment among Black youth, together with racism in the community, and in the policing of our cities. They point to the budget cuts and the problems facing newly arrived refugees and other immigrants, together with difficulties faced by minority youth in schools.

Radical critics of multiculturalism call for more rather than less government intervention. They deplore the rise of neo-fascist movements, and the spread of hate literature, and believe that the law must be strengthened to deal with these threats. They point to the need for recognition of foreign qualifications and job experience, to assist newcomers find suitable housing, and to improve language training programs. They recognize the need for better community health services and therapy for the victims of torture, and the trauma faced by many refugees. There is particular emphasis upon the status of minority women who experience "double" and sometimes "triple" jeopardy as a result of gender, colour and immigrant status. Some critics regard government funding for independent "Black," Muslim and Jewish schools (as well as the existing Catholic Separate school system) as appropriate. Radical critics also see multicultural programming as an educational tool that is needed, more than ever, to change the attitudes of the Canadian-born and longer established immigrants.

2) The liberal/humanist criticism, loudly voiced by writers such as Neil Bissoondath (1994), insist that cultures are dynamic, self-propelled and competing in a world system, where only the best will survive. They see government programs as perpetuating a nostalgic attachment to ancestral values and identities. These, in turn, impede a successful adjustment to Canada, as part of a global system. They are critical of those who condone the continued practise of female circumcision, and other behaviour which contravenes a more universalist interpretation of human rights. Thus Bissoondath rightly insists that shared ethnicity does not entail unanimity of vision. In his view, a wider sense of humanity must prevail over the nar- rowness of ethnicity. The liberal/humanist critics of multiculturalism see ethnicity as a voluntary expression of identity, to be largely confined to the family and community. They do not believe that government has a legitimate role to play in its promotion. For example, Reginald Bibby (1990) suggests that multiculturalism is dividing Canada against itself, creating a form of "mosaic madness." What is needed, he argues, is a stronger sense of national unity and an end to "hyphenated-Canadianism." Immigrants and their descendants should enjoy their own language and culture in the privacy of their homes, churches and community halls, but not expect governments to subsidise them. Nor should nostalgia for an ancestral past create divided loyalties, or invoke separatist passions.

3) The communitarian critique is implicit rather than explicit in their writings. In fact, the pluralistic, multicultural character of contemporary North American society is one of the things that writers, such as Amitai Etzioni (1991), appear to ignore when they promote the idea of constitutive moral communities. The promoters of "communitarianism," appear to have the ear of some politicians in Canada, Britain and the U.S. They argue that there are too many special interest groups asserting their rights, and making claims on the state and its resources. Presumably this includes the recipients of multicultural funding! They want more emphasis to be placed on duties, responsibilities and obligations, designed to further the common good. They seek to create and strengthen local communities of place, they promote the idea of a nation as a community, and emphasize the importance of a common language and religion. They assume it is possible to generate a consensus on fundamental values, and that these values can be enforced by moral persuasion, although coercion is not ruled out. The potentially fascist implications of the communitarian movement have not been lost on those who are sceptical of its claims (Bell 1993). In its extreme 
form, the "nationalist" view disapproves of any outward symbols of ethnic distinction, such as the turban or the hajib while, presumably, approving of the kilt and the stetson! Enforced conformity to a single nationalisticideology smacks of Nazism, and easily leads to anti-Semitism and other forms of intolerance.

4) The neo-conservative critics of multicultural programs see them as yet another example of unnecessary government control. Multicultural policies and practices involve interference in free market principles and individual freedoms. Affirmative action is seen as positive discrimination and contrary to the idea of "merit" as the sole criterion for admission to higher education, hiring and promotion. Employment Equity programs have been attacked as a form of discrimination against young, white males struggling to obtain a foothold, or to retain their advantage, in a rapidly changing employmentmarket. Multiculturalism, as a state supported program, is regarded as a luxury that a debt-ridden government can no longer afford. Together with legal aid, unemployment insurance and welfare, it must face budgetary cut-backs.

5) The "Objectivist" view espoused by the followers of Ayn Rand, represents an even stronger backlash against multiculturalism, particularly as it manifests itself in schools, colleges and educational curricula. They describe multiculturalism as a "virus" deliberately injected into the body politic in order to destroy it! The increasing number of "Black Studies," "Hispanic Studies," "Native Studies," and "Women's Studies" programs, are seen as threatening what they consider to be the canon of so-called "Western culture," which Objectivist philosophy regards as inherently superior to other traditions. They accuse those who identify with these ethnically defined programs as "racist," while the "objectivists," themselves, propagate an extremist view insisting on the superiority of Euro-American languages and cultures. The followers of Ayn Rand are equally critical of the influ- ence of postmodernism in philosophy and literature as taught in our universities today. Postmodernism, in rejecting the idea of "universal metanarratives," is seen as relativistic and fragmenting. ${ }^{3}$ Their answer is to reassert the primacy of so-called "western" values, particularly those of rightwing Americans.

We are all of us "immigrants to the twenty-first century." Multiculturalism is a "way of life" notjust in Canada, but in the United States, central and south America, Australia, most countries in western Europe and, indeed, in Africa and Asia too. As the new millennium approaches we recognize the postmodern potential for disintegration and fragmentation ...

\section{Notes}

1. Fortunately, I am not yet one of those "dead white anglo-European males" whose books, according to some critics, should be removed from the contemporary canon! My books have not been banned in Canada, although one I wrote forty years ago was banned in South Africa because of its criticism of apartheid.

2. The reality of a multicultural society should not be confused with the phenomenon of "carnivilization," in which selected aspects of a traditional culture are treated as a commodity. Events such as Caribana and Caravan, which purport to celebrate the multicultural character of Toronto, are commercial by-products of the globalization of tourism as an industry.

3. The "objectivist" argument was expressed by Dr. Gary Hull at a lecture given at York University, Toronto, March 20, 1995, titled "Your Professor's War Against Your Mind: The Black Hole of Postmodernism and Multiculturalism."

\section{References}

Bell, Daniel. 1993. Communitarianism and Its Critics. Oxford: Clarendon Press.

Bibby, Reginald Wayne. 1990. Mosaic Madness: The Poverty and Potential of Life in Canada. Don Mills, Ont.: Stoddart.

Bissoondath, Neil. 1994. Selling Illusions: The Cult of Multiculturalism in Canada. Toronto: Penguin Books.

Etzioni, Amitai. 1991. A Responsive Society: Collective Essays on Guiding Deliberate Social Change. San Francisco: Jossey-Bass Publishers. $\square$

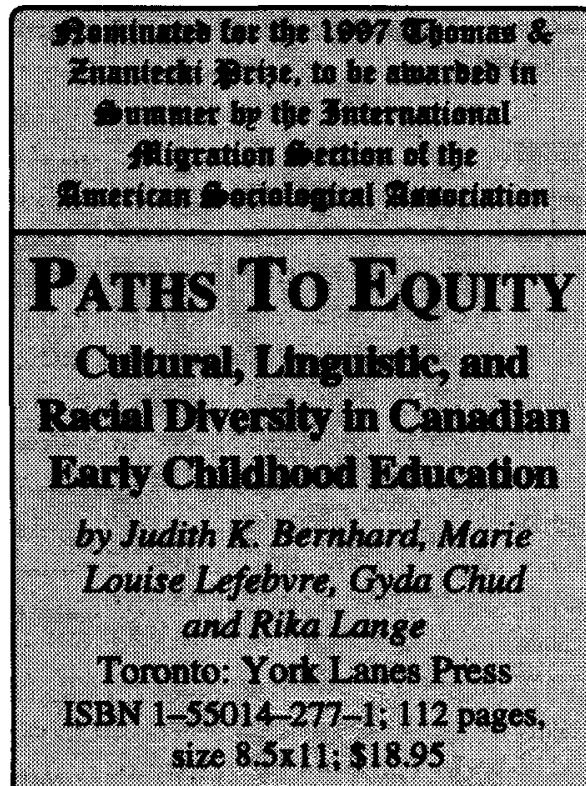

Porhis bo bquily is baved on an extensive abtion wide sudy of 77 childeare coneresin Moutreal, Toronto, and Van. couver or the culural, linguistic, and meial diversity in Comadian Finty Child. hood Education (ECE) The report perents the revilus this tudy on how the ECE syctent is retponding to the increasing diversity of contemporaty Canidim socicty.

A fully one thind of teachers inter. viewed in this stady terponded, at the ims of raduation from Late progarans: did not forl that hey were well pro. pared to wort ef foctively with children and paresis from diversobrek crowhds.

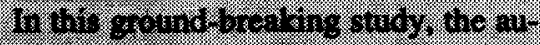

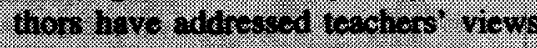

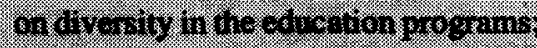
phenes difriculies in colliborating withr the cursent chitedica bystem

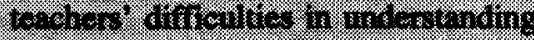

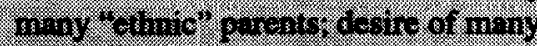
parcint Gor better communicecion with

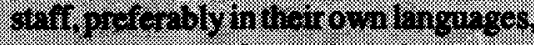
and for more information about their individual chidren and chinces for enceroro inputs and the evitence of some centinumg problons with racism, wrespective or the gool intontion

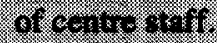

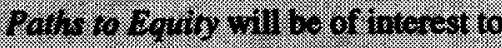
EOE Revily. poliey molkers. centr: supertions and ond and others inter

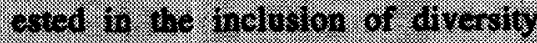

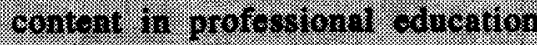

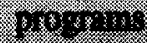

